\title{
The Effect of Learning Motivation on Student Achievement on Statistics
}

\author{
Dian Ari Widyastuti, Siti Muyana, Agungbudiprabowo \\ Department of Guidance and Counseling \\ Universitas Ahmad Dahlan \\ Yogyakarta, Indonesia \\ dian.widyastuti@bk.uad.ac.id
}

\begin{abstract}
The study aims to determine the effect of statistical learning motivation on statistical learning achievement on students of the Ahmad Dahlan University Guidance and Counseling Study Program. The study is a quantitative study with a correlational type. Respondents in this study were 220 students of the Ahmad Dahlan University Guidance and Counseling Study Program which were determined through a purposive sampling technique. Data collection uses motivation to learn statistics and statistical learning achievement data. Data analysis using simple linear regression. The results of data analysis stated that there was a significant effect between statistical learning motivation on statistical learning achievement on students of the Ahmad Dahlan University Guidance and Counseling Study Program. The results of the study contribute to the development of the lecture process of statistics in the Guidance and Counseling Study Program so that students as prospective counselors could have adequate competence in terms of data analysis in conducting research and in guidance and counseling services.
\end{abstract}

Keywords-learning motivation; guidance and counseling; statistics course

\section{INTRODUCTION}

The progress of science and technology cannot be separated from statistics. Researchers use statistics as a tool in understanding the symptoms they are observing. For statistical assistance, the findings produced by the researchers can be communicated to the public briefly and accurately. In everyday life, statistics is not a foreign term among lecturers and students because almost all of their careers struggle with statistics. Therefore, it cannot be denied if researchers, lecturers, students, and some parties are always related to statistics in their daily lives.

Statistics is one of the groups of mathematics. Furqon [1] states that mathematicians develop statistics on opportunity theory as a tool to help humans mathematically to solve various problems faced so that statistics cannot be separated from opportunity theory and are part of metamatika. Statistics can be interpreted as science that deals with ways of collecting, presenting, processing, analyzing data, and drawing conclusions [2]. Gunawan [2] further states that the method for collecting, compiling, analyzing, presenting data, and making conclusions is called statistics.
Statistical subjects in the Guidance and Counseling Study Program are very meaningful for students and can provide adequate competency provision in conducting research and when entering the workforce. Generally, current employment demands more analytical skills than doing procedural or mechanistic work so that in today's era, students need statistical learning to answer life's challenges in the arena of global competition. In addition, statistics can also be used to hone individual mindsets so that they can apply the knowledge and skills they have to solve problems in their lives.

Students in the Guidance and Counseling Study Program really need good statistical analysis skills in order to analyze the results of need assessment and research results. Therefore, students need to have statistical learning motivation because it is seen to be able to improve students' understanding and learning achievement in statistical subjects. The study aims to determine the effect of statistical learning motivation on statistical learning achievement on students of the Ahmad Dahlan University Guidance and Counseling Study Program. The results of the study can contribute to the development of the lecture process of statistics in the Guidance and Counseling Study Program so that students as prospective counselors can have adequate competence in terms of data analysis of research implementation as well as in guidance and counseling services.

\section{METHOD}

The study is a quantitative study with a correlational type. Respondents in this study were 220 students of the Ahmad Dahlan University Guidance and Counseling Study Program which were determined through a purposive sampling technique. Data collection uses motivation to learn statistics and statistical learning achievement data. Data analysis using simple linear regression.

\section{RESULTS AND DISCUSSION}

Student learning motivation in statistical subjects can affect student achievement in statistical subjects. This is evidenced by the results of simple linear regression analysis as in Table 1. Data on student learning achievement scores in the statistical subject can be seen from the accumulation of 
the final grades of students in the statistical subjects. The following are the results of a simple linear regression analysis with the help of statistical software.

The result shows simultaneously the variables of student learning motivation in statistical subjects having a contribution of 0.723 or $72.3 \%$. This indicates that student learning achievements in statistical subjects are able to be explained by student learning motivation in statistical subjects of $72.3 \%$, or in other words the contribution of student learning motivation in statistical subjects to student learning achievement in statistical subjects of $72.3 \%$, while the remaining $27.7 \%$ is the contribution of other variables outside the model.

Based on the statistical test results, $\mathrm{F}$ count of this study is 430.890 with a significance of 0.000 which is smaller than 0.05 , then a significant regression model or can be said to be feasible is used to predict student learning achievement in statistical subjects. This result also shows that there is a significant effect of statistical learning motivation variables on student learning achievement in statistical subjects.

Statistics are very closely related to the lives of individuals and the environment. Almost every day individuals are faced with statistical data. Therefore, statistics are useful for the lives of individuals. According to Lyman and Longnecker [3]:

"Statistics is the science of designing studies or experiments, collecting data and modeling / analyzing data for the pose of decision making and scientific discovery when the information is available both limited and variable. That is, statistics is the science of Learning from Data."

Statistics is a branch of science that learns about how to plan, collect, analyze, interpret and present data and draw conclusions based on data collection and analysis carried out. A collection of processed data will be able to produce an accurate data analysis.

The scope of statistics includes descriptive statistics and inferential statistics. Descriptive statistics include collecting data, compiling data, processing data, presenting data and analyzing numerical data while inferential statistics include probability, assessment and testing of hypotheses, correlations, and comparisons [4]. Statistics plays an important role in research, both in the preparation of models, the formulation of hypotheses, in the development of tools and instruments for data collection, preparation of research designs, and determination of samples and data analysis. According Lyman and Longnecker [3], the reasons for statistical learning are:

1) You need to know how to evaluate published numerical facts. 2) Studying statistics Your profession or employment requires you to interpret the results of sampling (surveys or experimentation) or employ statistical methods of analysis to make inferences in your work.
Based on this opinion it can be concluded that learning statistics functions to find out how to evaluate numerical data and interpret the results of data analysis.

Students can gain an understanding of the concepts and learning materials of statistical subjects if they have high learning motivation for statistical subjects. Motivation to learn itself is defined as an impulse arising from within because of influence from within an individual or influence from outside the individual that aims to achieve successful learning [5], [6]. According to Cotrus et al. [7] the motivation of students to learn lies in their desire to find the most appropriate cognitive strategies, which they believe will help in learning. Whether it's about organizing, repeating information, monitoring a comprehensive level or making connections between new knowledge and those obtained previously, each student, in part, sets the order of their priorities.

Low motivation for statistical learning has an impact on understanding statistical concepts. Some problems that require understanding statistical concepts have not yet been mastered optimally by students, such as the weak understanding of one concept with other concepts needed to solve statistical problems. Learning motivation is very important as a determinant of the success of student learning outcomes [6]. Students will achieve maximum statistical learning outcomes if they have the motivation to learn statistics. The higher the motivation, the better the learning outcomes. So motivation will always determine the intensity of learning efforts for students. In addition, learning motivation increases the speed of completing learning tasks and someone does everything to achieve goals [8]. Learsrning motivation also has an important influence on student learning attitudes and behavior [9].

Lecturers have a very important role in increasing student learning motivation so that students can also achieve optimal learning achievement. The lecturer is also responsible for determining the quantity and quality of the teaching that is carried out. Therefore, lecturers must think through and plan carefully in increasing learning opportunities for students and improving their teaching quality, especially statistical learning. Lecturers must be able to innovate in learning and motivate students to learn more actively, creatively, and systematically to find statistical knowledge independently. Students' creative thinking abilities cannot develop properly if the lecturer does not actively involve students in the learning process so that active learning strategies are needed so that students are intellectually, emotionally involved, and can improve soft skills [10], [11].

Statistical learning plays an important role in data analysis, especially in analyzing the data of assessment needs in guidance and counselling services and analysis of research data. Therefore, understanding of concepts and statistical material must be emphasized by lecturers to students. Usually, students who have idealistic thinking have good learning motivation [12]. However, it does not rule out the possibility that learning motivation can be possessed by all students. Therefore, all students of the guidance and counselling study program should have the motivation to 
learn statistical subjects so that students as prospective counsellors are competent in analyzing statistical data that is very useful in guidance and counselling services.

\section{CONCLUSION}

The results of the study shows that there is a significant influence of statistical learning motivation on statistical learning achievement. It is expected that the statistical lecturers in the Guidance and Counselling Study Program can internalize the motivation to learn statistics so that students can improve their statistical learning achievement. The results of the study can contribute to the development of the process of statistics in the Guidance and Counselling Study Program so that students as prospective counsellors can have adequate competence in terms of data analysis of research implementation as well as in guidance and counselling services.

\section{REFERENCES}

[1] Furqon. (2013). Statistika Terapan untuk Penelitian. Bandung: Alfabeta.

[2] Gunawan, Imam. (2015). Pengantar Statistika Inferensial. Jakarta: Rajawali Pers.

[3] Lyman, Ott and Michael Longnecker. (2010). An Introduction to statistics with data analysis. Belmont: Brooks/Cole,Cengage Learning.

[4] Hartono. 2009. Statistik untuk Penelitian. Yogyakarta: Pustaka Pelajar.

[5] Guay, F., Chanal, J., Ratelle, C. F., Marsh, H. W., Larose, S., \&Boivin, M. (2010). Intrinsic, identified, and controlled types of motivation for school subjects in young elementary school children. British Journal of Educational Psychology, 80(4), 711-735.

[6] Kariadinata, et al. 2019. Learning Motivation and Mathematical Understanding of Students of Islamic Junior High School Through Active Knowledge Sharing Strategy. Infinity Journal of Mathematic Education, 8(1), 31-42.

[7] Cotrus, A., Varga, P.I., Zetes, V. (2014). Comparative study between study tracks: math and sciences or humanities, regarding academic motivation and learning strategies in the 9th grade students. Procedia - Social and Behavioral Sciences, 128, 432 - 437.

[8] Bakar, Ramli. 2014. The Effect of Learning Motivation on Student's Productive Competencies In Vocational High School, West Sumatra. International Journal of Asian Social Science, 4(6), 722-732.

[9] Hakan, K. \& Munire, E. (2014). Academic Motivation: Gender, Domain and Grade Differences. Procedia - Social and Behavioral Sciences, $143,708-715$.

[10] Sugilar, H. (2013). Meningkatkan kemampuan berpikir kreatif dan disposisi matematik siswa madrasah tsanawiyah melalui pembelajaran generatif. Infinity Journal, 2(2), 156-168.

[11] Rosyana, T., Afrilianto, M., \& Senjayawati, E. (2018). The strategy of formulate-share-listen-create to improve vocational high school students'mathematical problem posing ability and mathematical disposition on probability concept. Infinity Journal, 7(1), 1-6.

[12] Palmer D. (2007). A motivational view of constructivist-informed teaching International Journal of Science Education, 27 (15), 18531881. 